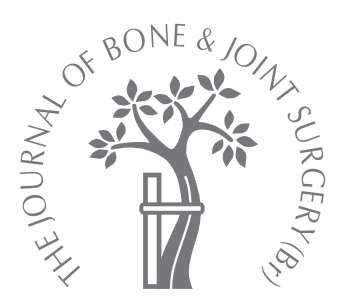

L. C. Biant,

G. Bentley

From The Royal

National

Orthopaedic

Hospital, Middlesex, England

- L. C. Biant, BSc, AFRCS Ed Specialist Registrar

a. G. Bentley, ChM, FRCS,

FMedSci, Emeritus Professor of

Orthopaedic Surgery

The Royal National

Orthopaedic Hospital, Brockley

Hill, Stanmore, Middlesex HA7

4LP, UK.

Correspondence should be sent to Ms Rosemary Dutton,

Secretary to Professor Bentley;

e-mail: Icbiant@yahoo.com

(C2007 British Editorial Society of Bone and Joint Surgery doi:10.1302/0301-620X.89B8. $18911 \$ 2.00$

$J$ Bone Joint Surg [Br] 2007;89-B:1110-14.

Received 15 November 2006 ;

Accepted after revision 14 May

2007

\title{
Stem cells and debrided waste
}

\author{
TWO ALTERNATIVE SOURCES OF CELLS FOR TRANSPLANTATION \\ OF CARTILAGE
}

\begin{abstract}
Implantation of autologous chondrocytes and matrix autologous chondrocytes are techniques of cartilage repair used in the young adult knee which require harvesting of healthy cartilage and which may cause iatrogenic damage to the joint. This study explores alternative sources of autologous cells.

Chondrocytes obtained from autologous bone-marrow-derived cells and those from the damaged cartilage within the lesion itself are shown to be viable alternatives to harvestderived cells. A sufficient number and quality of cells were obtained by the new techniques and may be suitable for autologous chondrocyte and matrix autologous chondrocyte implantation.
\end{abstract}

Autologous chondrocyte implantation (ACI) and matrix autologous chondrocyte implantation (MACI) are now established techniques for the repair of symptomatic isolated lesions of the articular cartilage in the young adult knee. ${ }^{1-6}$ The procedure involves two operative stages. First, the knee is assessed arthroscopically and, if a suitable lesion is identified, a sample of non-injured articular cartilage, approximately $1 \mathrm{~cm} \times 0.5 \mathrm{~cm}$ in size, is harvested from a minimally weight-bearing area, usually the femoral margin or trochlear margin. ${ }^{7}$ The harvested tissue is enzymatically digested and the liberated chondrocytes are expanded in a monolayer cell culture for a period of four weeks. The cells are recovered from the culture system using trypsinisation techniques. The second stage of the operation involves arthrotomy and direct assessment of the lesion. The area of injury is debrided down to bone and back to a stable rim of tissue. The debrided damaged cartilage from around the defect is discarded. Using the ACI technique, a flap of either periosteum, or a commercially produced collagen, ${ }^{8}$ is sutured over the defect and the seal is reinforced with tissue glue. The cultured chondrocytes are then injected beneath it. ${ }^{5}$ With the MACI technique, the chondrocytes are preloaded on to a matrix which is then cut to fit the defect.

One concern regarding ACI and MACI is the possible iatrogenic damage caused to unijured healthy articular cartilage during the harvesting procedure. While there are no studies as yet which give confirmed evidence of this iatrogenic damage resulting in a long-term problem in the knee, it is a violation of the normal articular cartilage which presumably has a function. Furthermore, it may take over ten years for any ill-effect of such harvesting to become manifest.

We have examined two alternative sources of cells for chondrocyte implantation which avoid the iatrogenic damage of the harvesting procedure namely, chondrocytes cultured from the debrided discarded tissue obtained from around the articular cartilage lesion itself and those cultured from human autologous stem cells from aspirates from the iliac-crest. Cells from these two sources were compared with cells cultured from the standard harvesting technique.

\section{Patients and Methods}

Human chondrocytes from 11 patients undergoing ACI were included in the study. They consented to undergo iliac-crest bone-marrow aspiration for stem cells while under general anaesthesia for their operation. Cells from the injured cartilage around the defect, which are normally discarded, were collected. Three patients had a lesion in the medial femoral condyle, three in the lateral femoral condyle, four had patellar lesions and one a lesion in the trochlear area.

Harvested tissue. At the initial arthroscopy, an area of non-injured articular cartilage of 1 $\mathrm{cm} \times 0.5 \mathrm{~cm}^{2}$ was harvested from a minimally weight-bearing area of the knee using a gouge. The harvested tissue was processed by 
STEM CELLS AND DEBRIDED WASTE

Table I. Number of cells obtained from the debrided margin of the defect before culture

\begin{tabular}{cllllll}
\hline Sample & Gender & $\begin{array}{l}\text { Age } \\
\text { (yrs) }\end{array}$ & $\begin{array}{l}\text { Location of } \\
\text { defect }^{*}\end{array}$ & $\begin{array}{l}\text { Size of defect after } \\
\text { debridement }(\mathbf{c m})\end{array}$ & $\begin{array}{l}\text { Size of tissue obtained } \\
\text { for enzyme digest }(\mathbf{c m})\end{array}$ & $\begin{array}{l}\text { Initial chondrocyte yield } \\
\text { before culture }\left(\times 10^{6} \text { cells) }\right.\end{array}$ \\
\hline 1 & M & 18 & Patella & $3.0 \times 2.0$ & $2.0 \times 2.0$ & 2.4 \\
2 & F & 33 & Patella & $1.0 \times 1.5$ & $1.0 \times 1.0$ & 0.7 \\
3 & M & 25 & MFC & $3.0 \times 1.8$ & $2.0 \times 1.5$ & 2.0 \\
4 & F & 39 & Patella & $3.0 \times 1.3$ & $2.0 \times 1.0$ & 1.6 \\
5 & M & 36 & Trochlea & $4.0 \times 1.5$ & $1.0 \times 1.0$ & 0.8 \\
6 & M & 39 & LFC & $1.0 \times 1.5$ & $1.0 \times 0.5$ & 0.8 \\
7 & F & 30 & LFC & $2.0 \times 1.5$ & $0.5 \times 0.5$ & 3.2 \\
8 & M & 28 & LFC & $2.0 \times 1.5$ & $1.8 \times 1.2$ & 2.6 \\
9 & M & 20 & MFC & $2.0 \times 2.0$ & $1.5 \times 1.5$ & 1.7 \\
10 & F & 25 & Patella & $1.5 \times 0.5$ & $0.8 \times 0.5$ & 2.4 \\
11 & F & 34 & MFC & $3.5 \times 1.5$ & $1.0 \times 1.0$ & \\
\hline * MFC, medial femoral condyle; LFC, lateral femoral condyle &
\end{tabular}

Table II. The mean concentration of glycosaminoglycan (GAG) in the cell pellets from the different origins and time points

\begin{tabular}{lll}
\hline Origin & Time-point (day) & GAG concentration $(\boldsymbol{\mu g} / \mathbf{m l})$ \\
\hline Defect & 7 & 4.9 \\
Harvest & 7 & 3.4 \\
Defect & 14 & 6.2 \\
Harvest & 14 & 6.0 \\
Defect & 21 & 7.8 \\
Harvest & 21 & 7.7 \\
Defect & 28 & 8.4 \\
Harvest & 28 & 8.0 \\
\hline
\end{tabular}

the supply laboratory of Verigen Transplantation Service International (Kastrup, Denmark). The chondrocytes were expanded in a monolayer culture system for a period of four weeks in a medium supplemented by autologous serum. The quantity and viability of the cells were assessed at the supply laboratory using a Trypan Blue exclusion dye test. ${ }^{9}$

The cells required for implantation were inserted into the patient's knee at the second operation. Cultured cells surplus to operative requirements were collected and counted. They were placed in a pellet culture at a density of 400000 cells per pellet by centrifugation at $500 \mathrm{~g}$ in 15 $\mathrm{ml}$ polypropylene tubes. ${ }^{10}$ After removal of the supernatant, cells were cultured at $37^{\circ} \mathrm{C}$ with $4 \% \mathrm{CO}_{2}$ in a medium containing Dulbecco's modified Eagle's medium, ${ }^{11}$ glucose, ITS+ Premix (Collaborative Biomedical Products, Bedford, Massachusetts), insulin $(6.25 \mu \mathrm{g} /$ $\mathrm{ml})$, transferrin $(6.25 \mu / \mathrm{ml})$, selenious acid $(6.25 \mu \mathrm{g} / \mathrm{ml})$, linoleic acid $(5.35 \mu \mathrm{g} / \mathrm{ml}$; BD Biosciences, Oxford, United Kingdom), bovine serum albumin $(1.25 \mathrm{mg} / \mathrm{ml})$, transforming growth factor beta 1 (recombinant human; R\&D Systems, Abingdon, United Kingdom), ascorbate, sodium pyruvate $(1 \mathrm{mM})$ and dexamethasone $\left(10^{-7} \mathrm{M}\right)$. The medium was changed every three days. Nine pellets were removed from the culture for analysis on days $7,14,21$ and 28 .
Table III. Difference in the mean quantity of DNA contained in the two groups of cells from the different origins and time points

\begin{tabular}{lcl}
\hline Origin & Time-point (day) & DNA concentration $(\mu \mathbf{g} / \mathbf{m l})$ \\
\hline Defect & 7 & 1.16 \\
Harvest & 7 & 1.23 \\
Defect & 14 & 1.99 \\
Harvest & 14 & 1.87 \\
Defect & 21 & 1.25 \\
Harvest & 21 & 1.23 \\
Defect & 28 & 1.25 \\
Harvest & 28 & 1.34 \\
\hline
\end{tabular}

Defect-derived chondrocytes. At the second operation, the lesion was debrided down to bone and back to a stable rim of tissue. The debrided tissue, which is usually discarded, was collected, measured, enzymatically digested with pronase and collagenase and the liberated chondrocytes counted. The cells were then cultured and expanded in a monolayer system identical to that of the conventionally harvested cells in an incubator at $37^{\circ} \mathrm{C}$ in a humidified atmosphere of $5 \% \mathrm{CO}_{2}$. The cell numbers were expanded until a minimum of 15 million cells had been obtained which usually occurred after two passages at confluence. Cells were recovered from the monolayer system by exposure to $0.25 \%$ trypsin for five minutes. They were then placed in pellet cultures at 400000 cells per pellet in an identical medium to that of the harvest-derived cells. Nine pellets were removed from culture for analysis on days 7 , 14,21 and 28.

Stem-cell-derived chondrocytes. A bone-marrow aspirate was taken from the posterior iliac crest. The needle was inserted and once it had contacted bone was advanced by rotating it slowly until the cortical bone was penetrated and the marrow cavity entered. Usually, a sudden change in 'give' was noted at this point. The stylet was removed and approximately $5 \mathrm{ml}$ of bone-marrow aspirate was taken into a syringe containing heparin. The marrow aspirate was processed immediately ${ }^{10,12}$ according to the method 
described by Wakitani et $\mathrm{al}^{13}$ which has been shown previously to yield mesenchymal stem cells from the aspirate. ${ }^{14}$ The aspirate was centrifuged at $180 \mathrm{~g}$ for five minutes. The supernatant was extracted and suspended in a medium containing $10 \%$ fetal calf serum (Life Technologies, Paisley, United Kingdom), $100 \mathrm{U} / \mathrm{ml}$ of penicillin, $100 \mu \mathrm{g} / \mathrm{ml}$ of streptomycin and $0.25 \mu \mathrm{g} / \mathrm{ml}$ of amphotericin and placed in a plastic flask. The cells were cultured in monolayer in a culture medium and conditions identical to those of the harvested and defect-derived cells. The medium was changed every three days. The cell numbers were expanded until a minimum of 15 million cells had been obtained, usually after two passages at confluence. Cells were removed from the monolayer system by exposure to $0.25 \%$ trypsin for five minutes and were transferred to a pellet culture system at a density of 400000 cells per pellet. Nine pellets were taken out of culture for analysis on days 7, 14, 21 and 28.

Biochemical analysis. Equivalent sets of pellets from each group were counted and analysed. The 1,9-dimethylmethylene blue (DMB) test ${ }^{15}$ was used to assess the content of sulphated glycosaminoglycan (GAG) in the samples. This indicates the presence and quantity of the matrix formed by viable chondrocytes. Cell pellets used for this test were digested at $60^{\circ} \mathrm{C}$ for one hour in a $0.5 \mathrm{ml}$ papain digest buffer containing $1 \mu \mathrm{g} / \mathrm{ml}$ of papain (Sigma, Poole, United Kingdom) sodium citrate $(55 \mathrm{mM})$, sodium chloride (150 mM), cysteine hydrochloride $(5 \mathrm{mM})$ and ethylenediamine tetraacetic acid (EDTA) $(5 \mathrm{mM}$; Merck, Poole, United Kingdom). A standard curve was created using chondroitin sulphate A from bovine trachea (Sigma). Cell samples were mixed with $250 \mu \mathrm{l}$ of DMB and the absorbance at $595 \mathrm{~mm}$ was determined using a microplate reader (Bio-Rad Ltd, Hemel Hempstead, United Kingdom). The DNA content, indicating the quantity of nuclei or number of cells present, was assessed using the Hoescht 33258 fluorometric assay (Sigma, Poole, United Kingdom). ${ }^{16} \mathrm{~A}$ standard curve was prepared using DNA from calf thymus (Sigma) and serial dilution techniques. Cell samples were digested in the papain buffer as above then $100 \mu \mathrm{g} / \mathrm{ml}$ of Hoechst (Sigma) at a concentration of $1 \mu \mathrm{g} / \mathrm{ml}$ were added to a $100 \mu \mathrm{l}$ aliquot of sample and standard. Analysis was performed using a microplate fluorimeter (Fluoroskan Ascent; LabSystems, Oxford, United Kingdom).

Histological and immunohistochemical analysis. This was performed on the samples. Pellets were initially dehydrated in $4 \%$ paraformaldehyde in $0.1 \mathrm{M}$ sodium cacodylate buffer at $\mathrm{pH} 7.4$, then dehydrated by sequential graded alcohol washes followed by xylene and set in paraffin blocks. Sections of $5 \mu \mathrm{m}$ were stained with Erlichs ${ }^{17}$ haematoxylin and eosin. A semiquantitative streptavidin biotin-immunoperoxidase immunolocalisation technique for type-II collagen was employed using antibodies to collagen type II (CIICI-Developmental Studies Hybridoma Bank, University of Iowa, Iowa). The technique is described in detail by Goldberg et al, ${ }^{11}$ and involves rehydration of sections and pretreatment in $0.1 \%$ trypsin and $0.1 \%$ $\mathrm{CaC}_{2}$ in distilled water at $37^{\circ} \mathrm{C}$ for ten minutes. Samples were washed and soaked in Tris-buffered saline for ten minutes. Rabbit serum (Dako A/S, Glostrup, Denmark) was added to suppress non-specific binding of IgG. Sections were then incubated with the antibodies to type-II collagen for 30 minutes. The streptavidin-biotin complex (Dako A/S) was then applied for 30 minutes to the samples followed by a solution which contained $0.7 \mathrm{mg} / \mathrm{ml}-1$ of 3,3-diaminobenzidide tetrahydrochloride, $0.7 \mathrm{mg} / \mathrm{nl}-1$ of urea, hydrogen peroxide and Tris buffer $0.06 \mathrm{M}$ (Sigma). Samples were washed and mounted.

\section{Results}

Debrided injured cartilage. The number of cells obtained before culture from the debrided lesion is shown in Table I. In all cases a sufficient number of viable chondrocytes from the defect-derived tissue was obtained after culture for implantation.

The mean concentration of glycosaminoglycan (GAG) in the cell pellets is shown in Table II. At each time point the pellets containing defect-derived chondrocytes contained a similar concentration of GAG as the harvest-derived chondrocytes. There was no difference in the mean quantity of DNA contained in the two groups of cells (Table III).

Histologically, no significant difference was seen between the pellets of chondrocytes from the defect and those from harvested cells (Fig. 1). Immunohistochemical analysis showed a similar positive staining for collagen type II in the chondrocyte pellets derived from the defect in the articular cartilage (Fig. 2) compared with the conventionally harvested cells, indicating that equivalent collagen was produced by the defect-derived cells.

Stem cells. It was possible to obtain sufficient stem cells for subsequent ACI and MACI for every patient from a bonemarrow aspirate of $5 \mathrm{ml}$. When chondrogenesis was induced in these cells and they were compared with harvestderived cells there was no difference in the GAG or chondrocyte DNA detected (Tables IV and V).

Immunohistochemical analysis demonstrated a similar positive staining for type II-collagen in the pellets of stemcell-derived chondrocytes compared with harvest-derived cells, indicating that equivalent collagen type II was produced by the stem-cell-derived cells.

Chondrocytes obtained from the debrided injured articular cartilage or from autologous bone-marrow aspirate were equivalent to those obtained by harvesting healthy cartilage. For most patients undergoing ACI, the iatrogenic insult to healthy articular cartilage can be avoided by harvesting damaged tissue from around the defect itself or using autologous stem-cell-derived cells.

\section{Discussion}

For each set of results analysed biochemically for GAG and DNA, the concentration in the defect-derived cells and the stem-cell-derived cells was at least as good as that obtained 


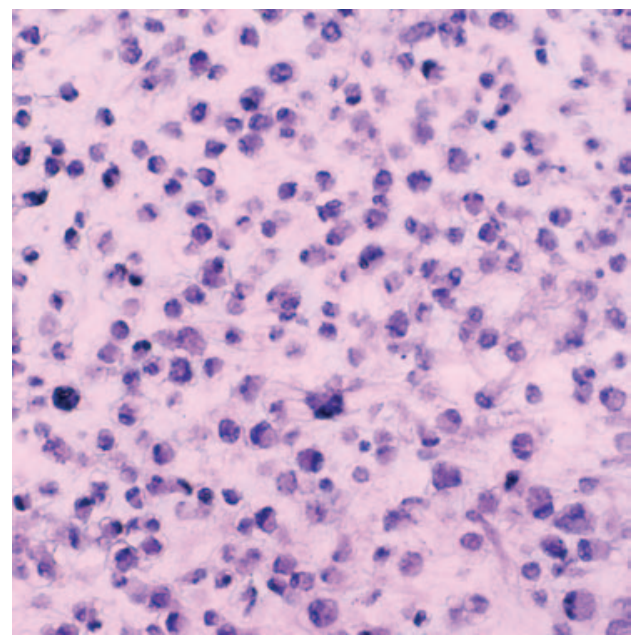

Fig. 1a

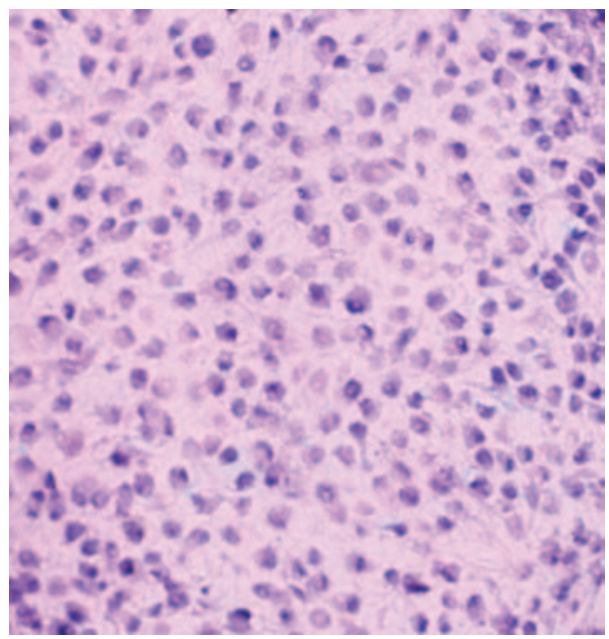

Fig. 1b

Photomicrographs of the pellet cultures at day seven in culture showing a) defect-derived cells and b) harvest-derived cells (haematoxylin and eosin $\times 20$ ).

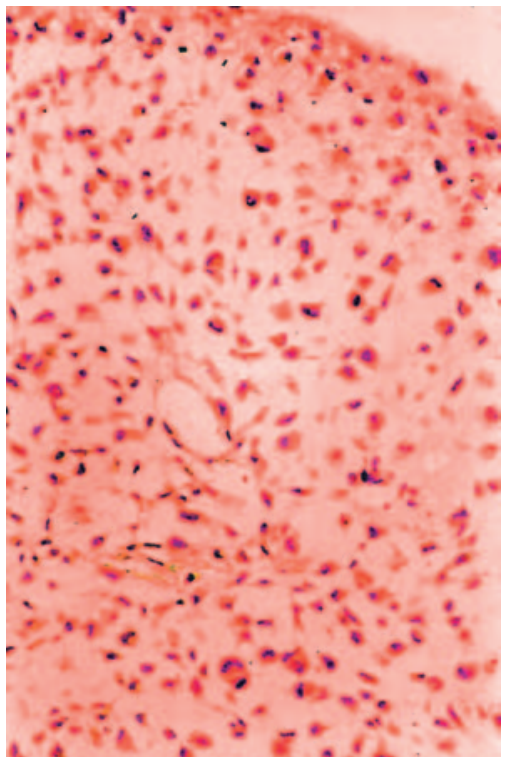

Fig. $2 \mathrm{a}$

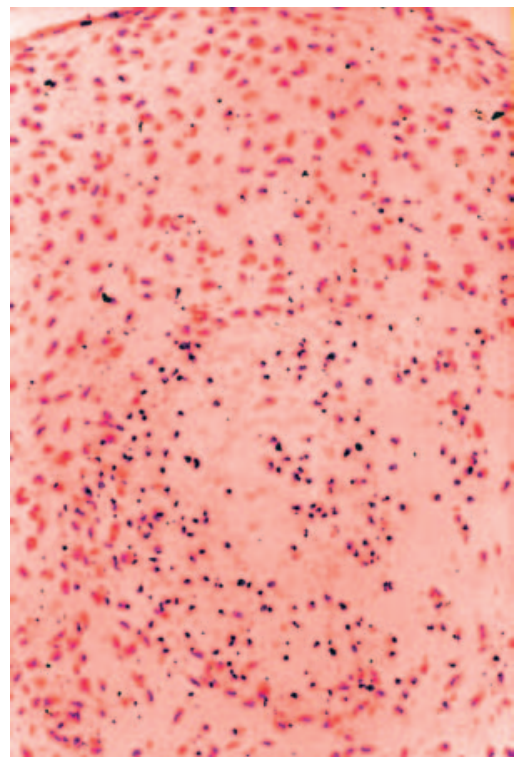

Fig. $2 b$

Semi-quantitative immunohistochemical photomicrographs for chondrocyte DNA in samples at day 21 showing a) defect-derived cells and b) harvest-derived cells $(\times 20)$.

from the conventionally harvested cells. On semiquantitative immunohistochemistry, the quantity of type-II collagen was equivalent. This showed that both of the newer methods described above give a sufficient number of chondrocytes for transplantation, allowing the procedure to be performed without damage to healthy tissue to gain a sample of chondrocytes for expansion in culture. The number of passages of cells in the monolayer culture system required to obtain sufficient cells from the defect or from bone-marrowderived cells was not greater that that for the conventionally harvested cells. There is no increased cost for the alternative sources of cells. 
Table IV. The mean concentration of glycosaminoglycan (GAG) in the cell pellets from different origins and time points

\begin{tabular}{lcl}
\hline Origin & Time-point (day) & GAG concentration $(\boldsymbol{\mu g} / \mathbf{m l})$ \\
\hline Harvest & 7 & 2.8 \\
Stem cell & 7 & 2.9 \\
Harvest & 14 & 5.7 \\
Stem cell & 14 & 4.3 \\
Harvest & 21 & 8.0 \\
Stem cell & 21 & 8.2
\end{tabular}

Table V. The mean concentration of DNA in the cell pellets from different origins and time points

\begin{tabular}{lcl}
\hline Origin & Time-point (day) & DNA concentration $(\boldsymbol{\mu g} / \mathbf{m l})$ \\
\hline Harvest & 7 & 1.51 \\
Stem cell & 7 & 1.57 \\
Harvest & 14 & 2.04 \\
Stem cell & 14 & 2.52 \\
Harvest & 21 & 1.64 \\
Stem cell & 21 & 2.47
\end{tabular}

It is thought that optimal repair of hyaline cartilage occurs when implanted cells mimic the embryological pattern of cartilage formation. ${ }^{18}$ It is possible that implanted cultured cells may de-differentiate in the defect of the articular cartilage, then begin the repair process. This would explain why early post-operative biopsies of sites of ACI repair can show immature hyaline cartilage and later more mature adult hyaline cartilage. ${ }^{19}$

However, chondrocytes in culture can produce hyaline cartilage and it is reasonable to attempt ACI and MACI of a defect of articular cartilage with cultured chondrocytes. Our study, and that of Chapinyo, Oakes and Van Damme ${ }^{20}$ have shown that the injured cartilage from around the defect yields sufficient chondrocytes of equivalent quality to those from uninjured cartilage. The injured hyaline cartilage itself is not capable of self-repair, but contains viable cells capable of differentiating into chondrocytes in culture. If they de-differentiate in the injured tissue, the culture process allows re-differentiation into chondrocytes.

We have shown that sufficient quality chondrocytes can be derived from adult stem cells for use in ACI or MACI and that these are readily available in a large quantity. When reviewing what is already known about the mechanisms of regeneration of articular cartilage, ${ }^{18,21}$ it may be that cells obtained from this source may give the optimal chance of a successful repair. ${ }^{22}$ Long-term studies on the clinical outcome of stem-cell repair of lesions of articular cartilage in man have yet to be performed.

No benefits in any form have been received or will be received from a commercial party related directly or indirectly to the subject of this article.

\section{References}

1. Peterson L, Minas T, Brittberg M, et al. Two- to 9-year outcome after autologous chondrocyte transplantation of the knee. Clin Orthop 2000;374:212-34.

2. Peterson L, Brittberg M, Kiviranta L, Akerlund EL, Lindahl A. Autologous chondrocyte transplantation: biomechanics and long-term durability. Am J Sports Med 2002;30:2-12.

3. Behrens P, Bitter T, Kurz B, Russlies M. Matrix-associated autologous chondrocyte transplantation/implantation (MACT/MACI): 5-year follow-up. Knee 2006;13:194-202.

4. Chu C, Convery FR, Akeson W, Meyers M, Amiel D. Articular cartilage transplantation: clinical results in the knee. Clin Orthop 1999;360:159-68.

5. Bentley G, Biant LC, Carrington RW, et al. A prospective, randomised comparison of autologous implantation versus mosaicplasty for osteochondral defects in the knee. J Bone Joint Surg [Br] 2003;85-B:223-30.

6. Bartlett W, Skinner JA, Gooding CR, et al. Autologous chondrocyte implantation versus matrix-induced autologous chondrocyte implantation for osteochondral defects of the knee: a prospective randomised study. J Bone Joint Surg [Br] 2005;87B:640-5.

7. Brittberg M, Lindahl A, Nilsson A, et al. Treatment of deep cartilage defects in the knee with autologous chondrocyte transplantation. N Eng/ J Med 1994;331:889-95.

8. Ehlers EM, Fuss M, Rohwedel J, et al. Development of a biocomposite to fill articular cartilage lesions: light, scanning and transmission electron microscopy of sheep chondrocytes cultured on a collagen I/III sponge. Ann Anat 1999;181:513-18.

9. Fong R, Kissmeyer-Nielsen F. A combined dye exclusion (trypan blue) and fluorochromatic technique for the microdroplet lymphocytoxity test. Tissue Antigens 1972;2:57-63.

10. Johnstone B, Hering TM, Caplan Al, Goldberg VM, Yoo JU. In vitro chondrogenesis of bone-marrow derived mesenchymal progenitor cells. Exp Cell Res 1998;238:265-72.

11. Goldberg AJ, Lee DA, Bader DL, Bentley G. Autologous chondrocyte implantation: culture in a TGF-beta-containing medium enhances there expression of a chondrocytic phenotype in passaged human chondrocytes in pellet culture. J Bone Joint Surg [Br] 2005;87-B:128-34.

12. Lennon DP, Haynesworth SE, Young RG, Dennis JE, Caplan AI. A chemically defined medium supports in vitro proliferation and maintains the osteochondral potential of rat marrow-derived mesenchymal stem cells. Exp Cell Res 1995;219:21122.

13. Wakitani S, Goto T, Pineda SJ, et al. Mesenchymal cell-based repair of large fullthickness defects of articular cartilage and underlying bone. J Bone Joint Surg [Am] 1994;76-A:579-92

14. Goshima J, Goldberg VM, Caplan Al. The osteogenic potential of cultureexpanded rat marrow mesenchymal cells assayed in vivo in calcium phosphate ceramic blocks. Clin Orthop 1991;262:298-311.

15. Farndale RW, Sayers CA, Barrett AJ. A direct spectrophytometric microassay for sulphated glycosaminoglycans in cartilage cultures. Connect Tissue Res 1982;9:247-

16. Rao J, Otto WR. Fluorometric DNA assay for cell growth estimation. Anal Biochem 1992;207:186-92.

17. Bancroft JD, Gamble M. Theory and practice of histological techniques. Fifth ed. Churchill Livingstone: Edinburgh, 2002:126.

18. Caplan Al, Elyaderani M, Mochizuki Y, Wakitani S, Goldberg M. Principles of cartilage repair and regeneration. Clin Orthop 1997;342:254-9.

19. Briggs TWR, Mahroof S, David LA, et al. Histological evaluation of chondral defects after autologous chondrocyte implantation of the knee. J Bone Joint Surg [Br] 2003:85-B:1077-83.

20. Chaipinyo K, Oakes BW, Van Damme MP. The use of debrided human articular cartilage for autologous chondrocyte implantation: maintenancy of chondrocyte differentiation and proliferation in type I collagen gels. J Orthop Res 2004;22:446-55.

21. Yoo JU, Bartel TJ, Nishimara K, et al. The chondrogenic potential of human bonemarrow-derived mesenchymal progenitor cells. J Bone Joint Surg [Am] 1998:80A:1745-57.

22. Caplan Al. Mesenchymal stem cells: cell based reconstructive therapy in orthopaedics. Tiss Eng 2005;11:1198-211. 